\title{
Effect of tissue culture cells in promoting prolonged survival of $N$. gonorrhoeae in artificial subcutaneous cavities of mice
}

\author{
SHEENA A. WAITKINS \\ Department of Medical Micrabiology, University of Sheffield Medical School, Beech Hill Road, \\ Sheffield, S10 2RX
}

Arko (1972) and Flynn and Waitkins (1973) reported that gonococci survived for varying times, in artificial subcutaneous chambers in mice and other animals, but there was a discrepancy in the survival times observed. Flynn and Waitkins (1973) found that the gonococci survived for 2 days, whereas Arko (1972) noted survival for periods up to several months. The reasons for these differences may be that Arko employed the synthetic steroid Dexamethasome (Assem Schering) and massive doses of gonococci approx. $0.25 \times 10^{8}$ per $\mathrm{ml}$.) as opposed to the $0.5 \times$ $10^{4}$ gonococci per ml. used by Flynn and Waitkins.

Phagocytosis of gonococci by tissue culture mouse fibroblast cells and their subsequent protection from the bactericidal action of rat serum was noted in the same year (Waitkins and Flynn, 1973). Clearly, if ingested gonococci were also protected in the mucous membrane of the genital tract, such cells containing surviving gonococci might be the most effective inoculum in the transmission of the disease.

In order to explore this possibility it was decided to try to establish a prolonged infection within the in vivo situation of a subcutaneous cavity of the mou'se. These cavities gave free access to the mouse's immunological defence mechanisms, both humoral and cellular, and because of this it seemed an ideal system to investigate the fate of the gonococcus.

\section{Material and methods \\ ANTIBIOTICS}

These were added to the tissue growth medium in the following concentrations: Vancomycin $\mathrm{HCl}$ (Lilly) $5 \mu \mathrm{g} . / \mathrm{ml}$. , penicillin (Vestric) 100 units/ml., streptomycin $100 \mu \mathrm{g} . / \mathrm{ml}$., and nystatin $25 \mathrm{i} . \mathrm{u} . / \mathrm{ml}$.

MEDIA

5 per cent. lysed horse-blood agar, prepared using Columbia agar (Oxoid) $39 \mathrm{~g}$. distilled water 1,000 ml. The agar

Received for publication March 21, 1975

Address for reprints: Cross-Infection Reference Laboratory, Central Public Health Laboratory, Colindale Avenue, London NW9 5HT was soaked for $15 \mathrm{~min} .$, mixed, and autoclaved at $121^{\circ} \mathrm{C}$ for $15 \mathrm{~min}$. When it had cooled to $55^{\circ} \mathrm{C}, 50 \mathrm{ml}$. sterile horse blood (Wellcome) lysed by repeated freezing and thawing was added.

Difco G.C. Medium Base plus Defined Supplement (GCMB), prepared as described by White and Kellogg (1965).

1 per cent. Glycerol peptone broth. $10 \mathrm{ml}$. of a 1 per cent. peptone broth was added to $10 \mathrm{ml}$. of 8 per cent. glycerol.

\section{Tissue culture media}

Eagle's Minimum Essential Medium (MEM) was obtained as a ten times concentrated stock solution from Wellcome Reagents Ltd. (Eagle, 1959).

Eagle's Growth Medium (EGM). $100 \mathrm{ml}$. MEM, $100 \mathrm{ml}$. calf serum (Biocult), and $20 \mathrm{ml}$. of 4.4 per cent. sodium bicarbonate were added to $780 \mathrm{ml}$ deionized water.

Eagle's Maintenance Medium (EMM). As for EGM, but $20 \mathrm{ml}$. calf serum were added instead of $100 \mathrm{ml}$. Medium '199' (Wellcome). Stock solution diluted 1 in 10 with distilled water, plus $0.85 \mathrm{mg}$./litre sodium bicarbonate (Morgan, Morton, and Parker 1950).

Dulbecco solution, $p H$ 7.3. Tablets for preparing Dulbecco A (Oxoid Ltd.) were dissolved in $100 \mathrm{ml}$. distilled water, autoclaved at $115^{\circ} \mathrm{C}$ for $10 \mathrm{~min}$. Full Dulbecco Saline (PBS) was prepared as described by Dulbecco and Vogt (1954).

Versene solution. $0 \cdot 2 \mathrm{~g}$. Ethylene diamine tetra-acetic acid was added to 1 litre of Dulbecco $\mathrm{A}$, and the pH adjusted to $7 \cdot 4$. It was sterilized by autoclaving at $115^{\circ} \mathrm{C}$ for $10 \mathrm{~min}$., and dispensed asceptically into sterile bottles.

Electron microscope solutions. 3 per cent. gluteraldehyde solution was prepared from 25 per cent. stock solution diluted in phosphate buffer $\mathrm{pH} 7 \cdot 3$.

Sucrose phosphate buffer ( 0.2 molar). $13.68 \mathrm{~g}$. sucrose was added to $100 \mathrm{ml}$. phosphate buffer $\mathrm{pH} \mathrm{7 \cdot 3}$. It was dissolved and sterilized by Seitz filtration.

TEST ORGANISM

The strain of $N$. gonorrhoeae (82406) used was isolated from a patient attending the Sheffield Venereal Disease Clinic. It was initially grown on 5 per cent. lysed horseblood agar with 1 per cent. vancomycin $(5 \mu \mathrm{g} . / \mathrm{ml}$.). It was identified by Gram's stain, a positive oxidase reaction, and fermentation of glucose but not maltose or sucrose. 
Fermentations were tested in a modified Difco GC medium base, with 1 per cent. of the sugar (Flynn and Waitkins, 1972). After one subculture it was preserved by 'snap freezing' in liquid $\mathrm{N}_{2}$ with 1 per cent. glycerol peptone broth as suspending medium. Kellogg's Type I colonies were used in these experments (Kellogg, Peacock, Deacon, Brown, and Pakle, 1963).

MICE

Inbred strains of Balb/C mice (Sheffield strain), varying in weight from 15 to 20 g., were used. They were fed a standard diet and water was given ad lib.

\section{SUBCUTANEOUS CAVITIES}

Artificial chambers were made in the subcutaneous tissues of the mice as described by Flynn and Waitkins (1973) (Figs 1 and 2).

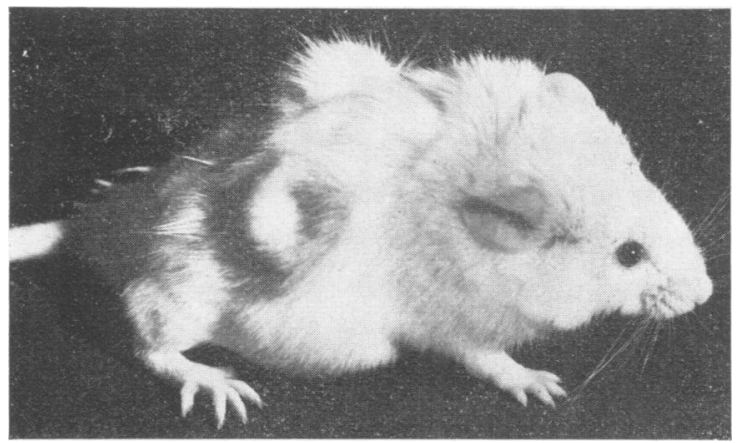

FIG. 1 Mouse with two vinyl rings in position

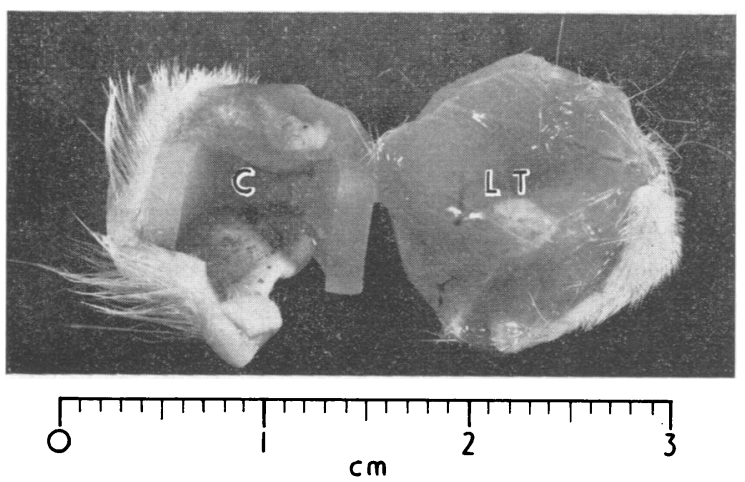

FIG. 2 Cross-section of subcutaneous cavity. Note layer of tissue $(L T)$ on inside of cavity forming a complete cavity $(C)$

TISSUE CULTURES OF BALB/C INBRED MOUSE CELLS

Primary cell cultures were prepared from 14 to 16 -day-old embryos. These were removed aseptically from the pregnant animal and skinned; the feet, head, and tail were removed and the remaining tissue chopped into fine pieces with scalpels in ' 199 ' medium. The fragments were then trypsinized with 0.25 per cent. trypsin in phosphate buffered saline $\mathrm{pH} 7 \cdot 3$, and left for $30 \mathrm{~min}$. at $37^{\circ} \mathrm{C}$. After this time, the trypsin was discarded completely, and the trypsination repeated three times, the discarded trypsin supernatants were collected and 10 per cent. serum added to stop the action of the trypsin. The final solution was then centrifuged at 800 r.p.m. for $5 \mathrm{~min}$, and the deposit washed in ' 199 ' medium. This procedure was repeated once. The resulting deposit of 'cells' was then re-suspended in EGM containing antibiotics. The cell suspension was then diluted with EGM and dispensed into $20 \mathrm{oz}$. bottles at a concentration of approximately $10^{6} \mathrm{cells} / \mathrm{ml}$. A confluent cell sheet was normally obtained in 3 to 4 days.

Just before inoculation with $N$. gonorrhoeae, the overlay was poured off and the monolayer was thoroughly washed several times with warmed Dulbecco saline to remove all antibiotics. Finally, fresh Eagle's medium without antibiotics was added.

Previous observations by our group (Waitkins and Flynn, 1973) indicated that the greatest engulfment of gonococci occurred after $8 \mathrm{hrs}$ ' incubation. For this reason the tissue culture cells were inoculated with $5 \times 10^{8}$ gonococci $/ \mathrm{ml}$. and incubated at $37^{\circ} \mathrm{C}$ for $8 \mathrm{hrs}$. The overlay was then replaced with fresh Eagle's medium containing 20 per cent. neat rat serum (which is bactericidal for the gonococcus), and the monolayer exposed to this environment for $30 \mathrm{~min}$. The rat serum kills off all extracellular gonococci (Flynn, 1972). The monolayer was then washed thoroughly with PBS to remove all rat serum and broken up with a rubber-tipped glass rod. These tissue culture cells containing gonococci were then centrifuged at 800 r.p.m. for $5 \mathrm{~min}$, to pack down the cells. The packed pellet was then re-suspended in $5 \mathrm{ml}$. PBS solution and the number of gonococci $/ \mathrm{ml}$. estimated by the technique of Miles, Misra, and Irwin (1938). $0.2 \mathrm{ml}$. volumes of $5 \times 10^{4}$ gonococci $/ \mathrm{ml}$. in tissue culture cells were inoculated into the right chamber of each mouse. Into the left chamber $0 \cdot 2 \mathrm{ml}$. volume of gonococci $\left(5 \times 10^{4}\right.$ per ml.) without tissue culture were inoculated. A control of tissue culture cells alone $\left(1 \times 10^{6}\right.$ cells $/ \mathrm{ml}$. $)$ was inoculated into the right and left chambers of a further three mice.

To prove that the gonococci were truly intracellular within the tissue culture cells, thin sections of these cultures which had been exposed for $8 \mathrm{hrs}$ to $N$. gonorrhoeae were cut and examined under the electron microscope as described below (Fig. 3, overleaf).

\section{ELECTRON MICROSCOPY}

A preparation that had been incubating for $8 \mathrm{hrs}$ was washed twice with warmed PBS, and versene was added to break up the monolayer of cells. The dispersed cells were gently centrifuged at 400 r.p.m. for $4 \mathrm{hrs}$ and fixed with 3 per cent. gluteraldehyde at $4^{\circ} \mathrm{C}$ for $2 \mathrm{hrs}$. The resulting pellet was washed gently three times in sucrosephosphate buffer over a period of $24 \mathrm{hrs}$. The pellet was finally fixed in 2 per cent. unbuffered osmium tetra-oxide, block stained with 0.5 per cent. uranyl acetate $(\mathrm{pH} 5.0)$, dehydrated with increasing concentrations of alcohol, and impregnated with Araldite. Sections were cut by an ultramicrotome and stained with Reynolds' lead citrate. An A.E.I. EM/81 electron microscope was used for viewing.

\section{HISTOLOGICAL PREPARATIONS}

Haematoxylin and eosin stained thin sections of the walls of the subcutaneous cavities after inoculation were 


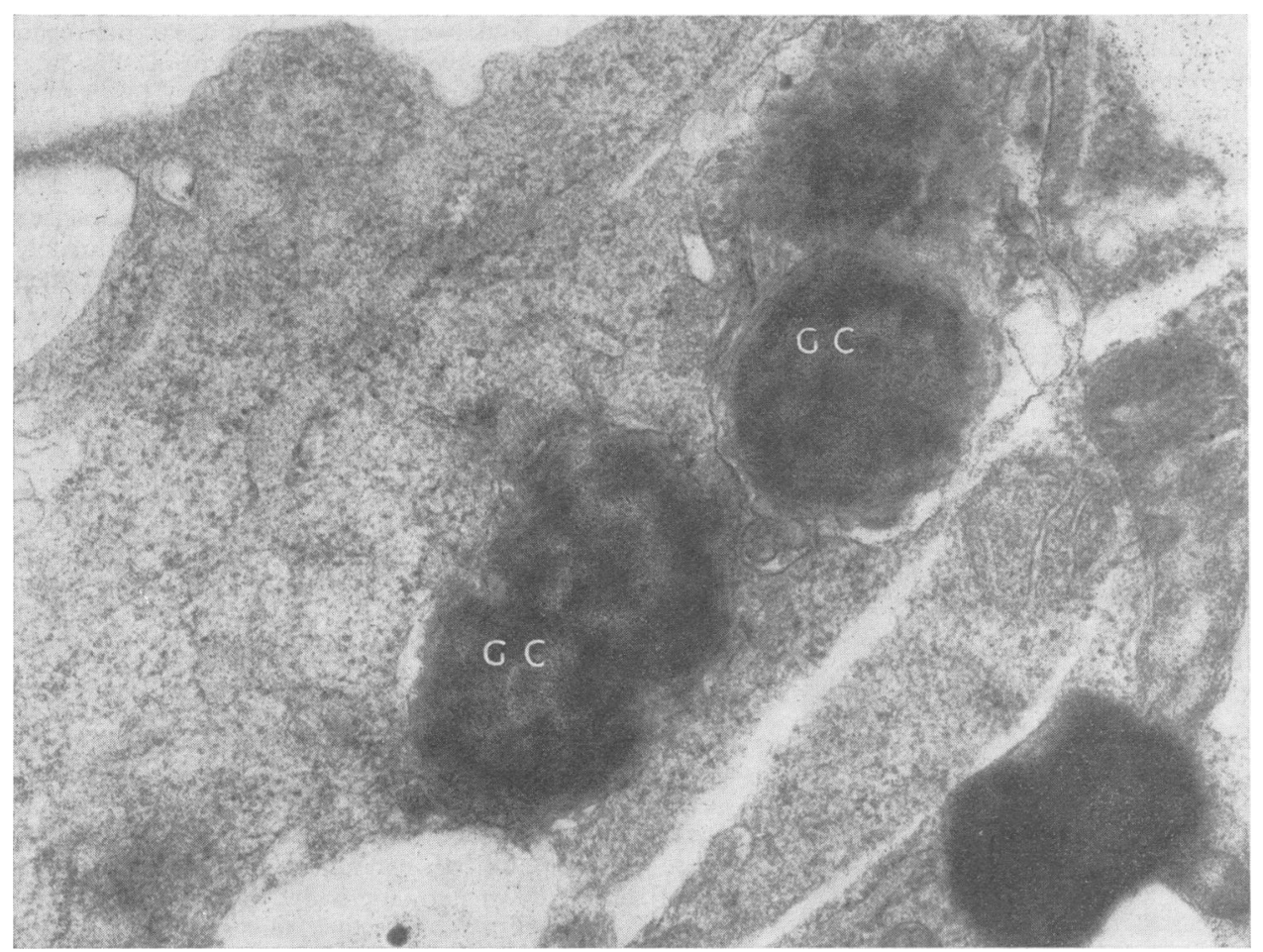

FIG. 3 Electron photomicrograph of Balb/C mouse tissue culture cells, $8 \mathrm{hrs}$ after inoculation with N. gonorrhoeae. Gonococci (GC) can be clearly seen inside the cell. $E M \times 10,000$

examined at 0,4 , and 10 days. Material fixed in Bouin's fixative was transferred into 80 per cent. alcohol and then processed through alcohol, xylol, to paraffin wax. Sections $5 \mu \mathrm{m}$. thick were cut, mounted on glass slides, dried at $37^{\circ} \mathrm{C}$ overnight, stained in Harris haematoxylin and counter-stained in eosin. They were then dehydrated in alcohol, cleared in xylol, and mounted in Piccolyte resin.

\section{Results}

The mice were observed over a 14-day period and attempts were made to recover $N$. gonorrhoeae from the chambers every $24 \mathrm{hrs}$. This was done aseptically using a syringe with a fine needle to aspirate one or two drops of fluid from the chamber on to 5 per cent. lysed horse blood agar, and GCMB agar and also on to clean microscope slides which were stained with haematoxylin and eosin and by Gram's method. The Table shows that, in the chambers inoculated with gonococci alone, organisms could be detected for only 3 days, whereas intracellular gonococci within cell cultures survived for up to 10 days. No Type IV gonococci could be isolated from the chambers and therefore virulent Type I did not degenerate to avirulent Type IV.

The histological sections of the subcutaneous cavities showed that, during the period of time studied, there was a massive increase in polymorphonuclear cells. After 1 day, both cavities, either containing gonococci alone or with tissue cells and gonococci, showed little polymorphonuclear invasion into the site (Fig. 4 ); by 4 days the cavity containing gonococci revealed only extensive infiltration of polymorphs and lymphocytes (Fig. 5), while the gonococcus itself could not be cultured from the cavity. On the other hand, at 4 days, the cavity which had been inoculated with tissue culture cells

TABLE Number of animals from which viable N. gonorrhoeae could be recovered on 5 per cent. horse blood agar. 24 mice were inoculated

\begin{tabular}{|c|c|c|c|c|c|c|c|c|c|c|c|c|c|c|}
\hline Chamber & \multicolumn{14}{|c|}{ No. of days } \\
\hline Right: Live gonococci within tissue culture cells & 24 & 24 & $\overline{24}$ & $\overline{24}$ & $\overline{20}$ & $\overline{20}$ & $\overline{16}$ & $\overline{9}$ & $\overline{4}$ & $\overline{1}$ & $\overline{0}$ & $\overline{0}$ & $\overline{0}$ & $\overrightarrow{0}$ \\
\hline Left: Live gonococci only & 24 & $\overline{10}$ & 1 & $\overline{0}$ & 0 & 0 & 0 & 0 & 0 & 0 & 0 & 0 & $\mathbf{0}$ & 0 \\
\hline
\end{tabular}




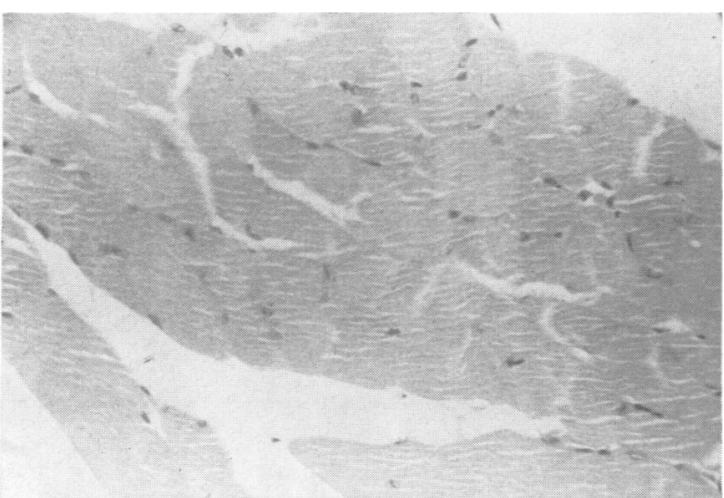

FIG. 4 Histological section of a cavity on Day 1 after inoculation. Very few polymorphs can be seen. Haematoxylin and eosin. $\times 270$

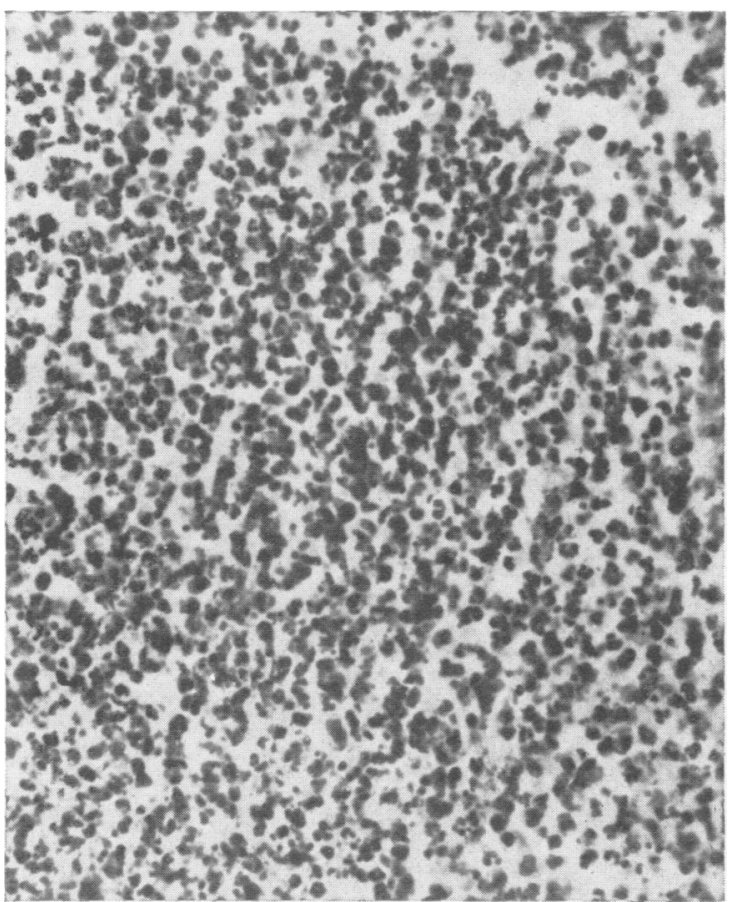

FI G. 5 Histological section of cavity 4 days after inoculation with gonococci alone. Large numbers of polymorphs and lymphocytes can be seen invading the tissues. Haematoxylin and eosin. $\times 460$

containing gonococci showed little polymorph invasion, while viable gonococci could still be cultured (Fig. 6). By day 10 there was a polymorph and lymphocyte invasion into the cavity containing gonococci inside tissue culture cells (Fig. 7), similar to that seen at day 4 in the gonococci alone cavity indicating that the gonococcus was now being destroyed by the cellular response of the mouse;

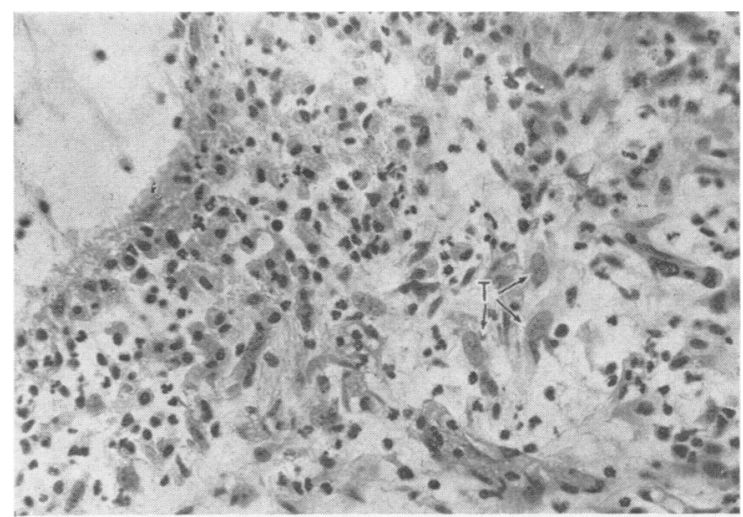

FIG. 6 Histological section of cavity 4 days after inoculation with gonococci inside tissue culture cells. Much smaller numbers of polymorphs can be seen. Note tissue culture cells $(T)$ still adhering to cavity. Haematoxylin and eosin. $\times 460$

this was substantiated by the complete failure to recover live, viable gonococci after day 10 from cavities which had been inoculated with tissue culture cells containing gonococci.

Histological sections from control mice, which had not been inoculated with any form of gonococci or tissue culture cells, showed little evidence of immunological cellular reaction. However, sections from mice which had tissue culture cells inoculated into them again revealed polymorph and lymphocyte invasion by the 10th day (Fig. 8), but little polymorph invasion on the 4th day; these results were almost identical to those of the cavities containing tissue cells and gonococci.

\section{Discussion}

It has been observed previously that gonococci are engulfed and protected within tissue culture cells (Waitkins and Flynn, 1973) and in human epithelial cells from urethral pus (Waitkins, Flynn, and Carr, 1973). We suggested that these epithelial cells containing gonococci might be significant, particularly in the transmission of the disease. From the present series of experiments, it is clear that gonococci which have not been protected from the host defence mechanism are more rapidly destroyed than gonococci protected within tissue culture cells, probably because they can establish themselves and survive the immunological attack by the host. Fig. 6 shows clearly that, after 4 days, tissue culture cells were still intact within the cavities, perhaps even attached to them. The failure of the gonococcus to survive beyond 10 days was probably due to graft rejection, which caused the destruction of the tissue culture cells and the death of the gonococci they contained. 


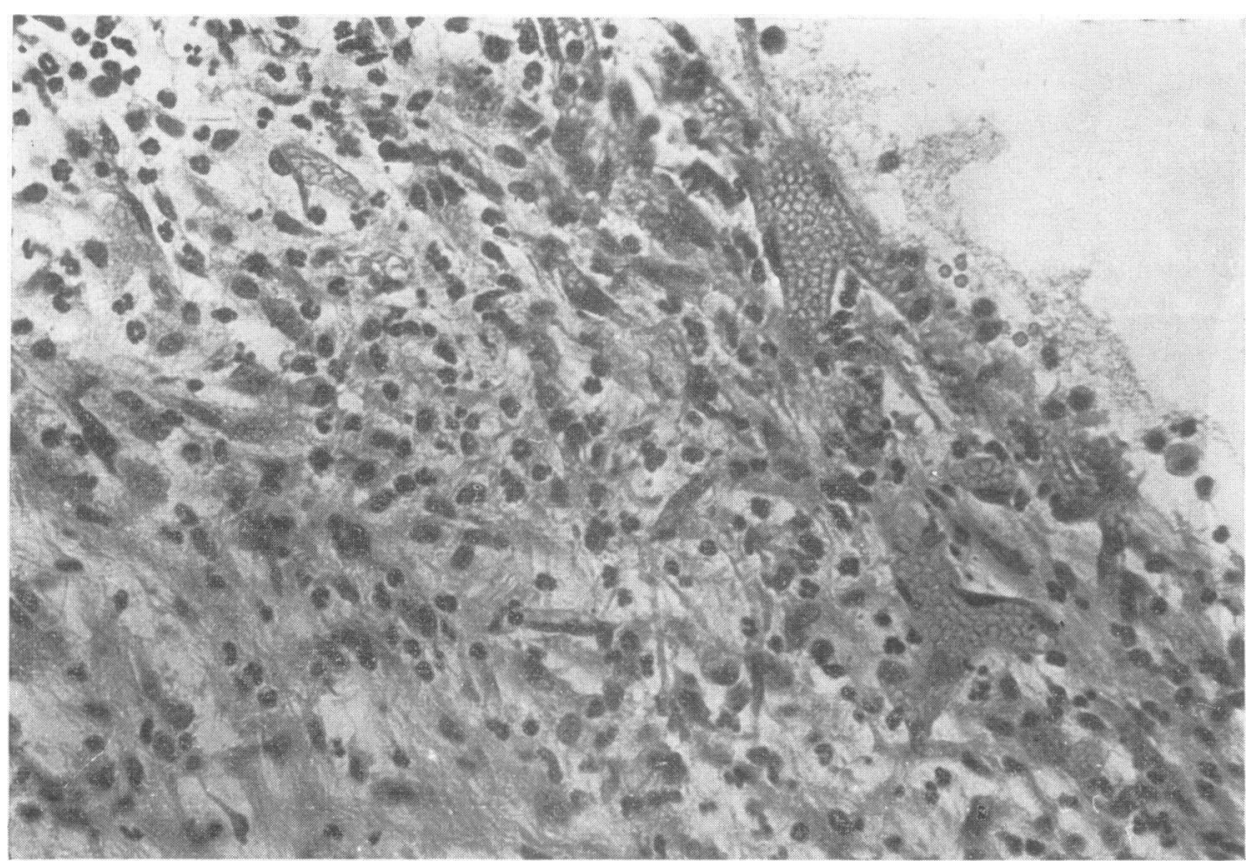

FIG. 7 Histological section of cavity 10 days after inoculation with gonococci inside tissue culture cells.

Large numbers of polymorphs and some lymphocytes can be seen. Haematoxylin and eosin. $\times 460$

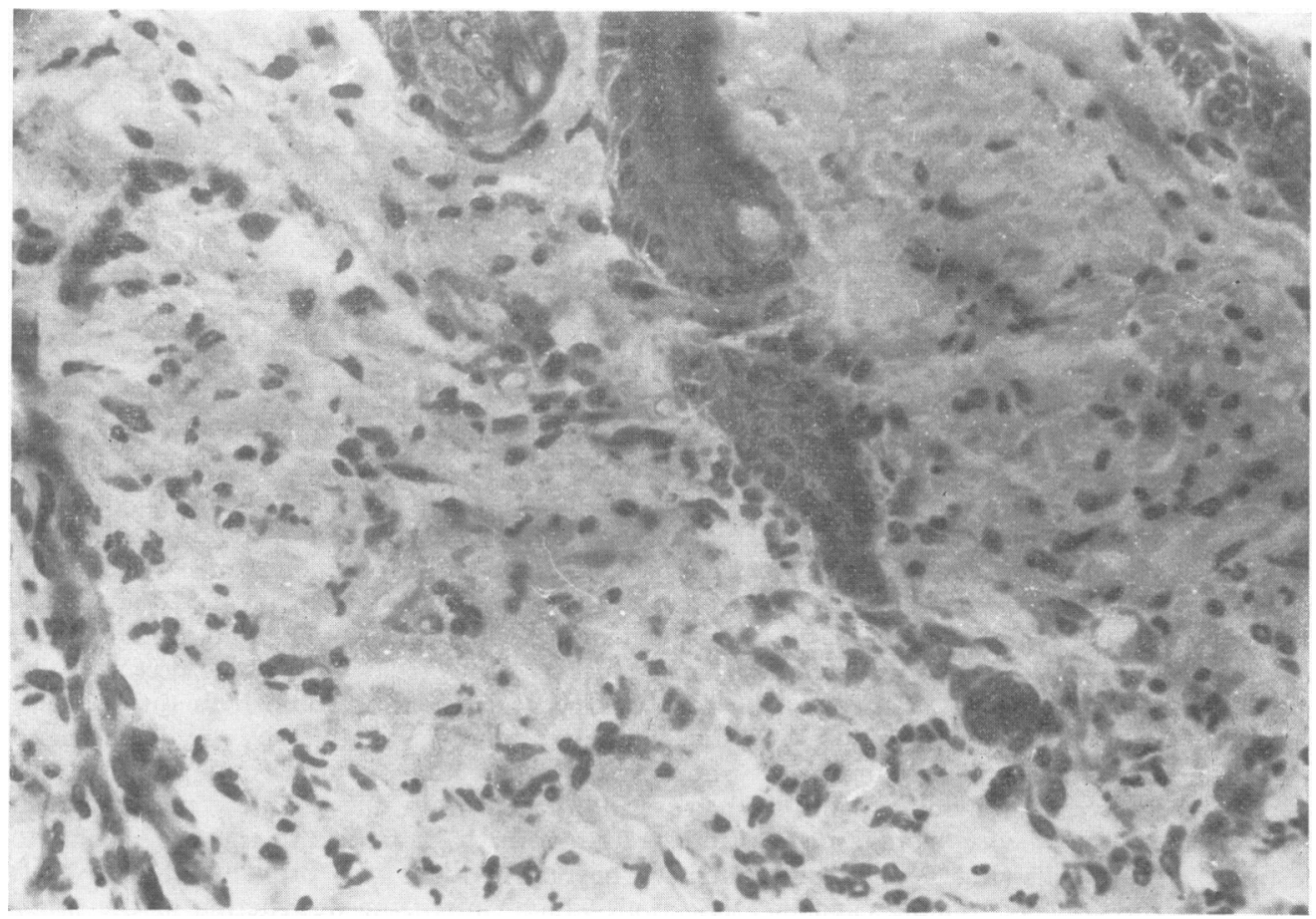

FIG. 8 Histological section of cavity 10 days after inoculation with tissue culture cells alone. Polymorph and lymphocyte invasion suggests immunological rejection of tissue cells. Haematoxylin and eosin. $\times 460$ 


\section{Summary}

Both tissue culture cells and human epithelial cells ingest gonococci, and subsequently protect them from the lethal action of various bactericidal agents. Using the convenient chamber produced by the subcutaneous insertion of a polyvinyl ring, the fate of the gonococci in mice was studied in vivo. Both humoral and cellular factors have free access to the organisms, and under normal circumstances these do not survive longer than 3 days. However, when gonococci were protected within tissue culture cells, their survival was prolonged. Only eventual graft rejection caused the death of the tissue culture cells and gonococci contained within them.

I wish to thank the Medical Research Council for financial assistance, Professor M. G. McEntegart for his help in preparing this manuscript, Dr. I. A. Carr and Mr. P. Morris, Department of Pathology, Weston Park Hospital, for their help with the electron microscopy, and Mrs. J. Gascoigne for technical assistance.

\section{References}

ARko, R. J. (1972) Science, 177, 1200

Dulbecco, R., and Vogt, M. (1954) f. exp. Med., 99, 167

EAGLE, H. (1959) Science, 130, 432

FLYNN, J. (1972) 'Studies on the factors which determine the resistance of small laboratory animals to infection with Neisseria gonorrhoeae'. M.D. Thesis, University of Sheffield.

and Waitkins, S. A. (1972) f. clin. Path., 25, 525

- - (1973) Brit. F. vener. Dis., 49, 432

Kellogg, D. S., JR., Peacock, W. L., Deacon, W. E., Brown, L., and PIRKLE, C. I. (1963) f. Bact., 85, 1274

Miles, A. A., MisRa, S. S., and IRWIN, J. O. (1938) f. Hyg. (Camb.), 38, 732

Morgan, J. F., Morton, H. J., and Parker, R. C. (1950) Proc. Soc. exp. Biol. (N.Y.), 73, 1

Waitkins, S. A., and FlynN, J. (1973) f. med. Microbiol., 6, 399

- - - and CARR, I. A. (1973) 'The Ingestion of Gonococci by Epithelial Cells'. 126th Meeting of the Pathological Society of Great Britain and Ireland.

White, L. A., and KellogG, D. S., JR. (1965) Appl. Microbiol., 13, 171 